\title{
A Comparative Study on Cultural Beliefs between Miluotuo and Homeric Epics \\ Yu Zhang ${ }^{*}$
}

Associate Professor, School of Foreign Languages at Baise University, Baise, Guangxi, China

DOI: $\underline{10.36347 / \text { sjahss.2020.v08i05.003 }}$

| Received: 30.04 .2020 | Accepted: 08.05.2020 | Published: 16.05.2020

*Corresponding author: Yu Zhang

\section{Abstract}

Bunu Yao's oral epic Miluotuo, one of the national intangible cultural heritage in People's Republic of China, occupies the core position in the culture of Yao ethnic group. Likewise, the Homeric Epics represents the western oral epic tradition, having profound influence on the western culture. A comparative analysis between the two in religious beliefs, world outlook, values, ways of thinking shows the difference of cultural beliefs embodied in them which can function as the basis for choosing translation strategies and then facilitating the transmission of Miluotuo worldwide.

Keywords: Miluotuo; Homeric Epics; cultural beliefs; cultural universality.

Copyright @ 2020: This is an open-access article distributed under the terms of the Creative Commons Attribution license which permits unrestricted use, distribution, and reproduction in any medium for non-commercial use (NonCommercial, or CC-BY-NC) provided the original author and source are credited.

\section{INTRODUCTION}

Miluotuo is the genesis epic of Bunu [pronounced " $\mathrm{jo}^{8} \mathrm{tse}^{2}$ " in Yao language], one of the branches of Yao People [ $\left[\mathrm{han}^{1} \mathrm{kan}^{3}\right]$ in China. It combines the myth, genesis and heroic elements together in its contents, while centering on the story of the creator goddess, Miluotuo who creates the human world, makes laws and blesses human beings. It is spread widely among the people in Duan, Dahua, Bama, Tiandong, Longan, Donglan, Fengshan, and Lingyun in Guangxi, China. As it carries out the essence of Yao culture, such as its history, culture, ethnic belief, philosophy, and arts, it is called the encyclopedia of Yao society. In 2011, it was included in the national intangible cultural heritage list. Since Yao people have no writing system in their language, the epic is passed down in oral form. The following lines are the opening of the long poem in IPA with their English translation:

$$
\begin{aligned}
& \text { jo }{ }^{8} \text { tse }^{2} \text { no } \varepsilon^{2} \text { no } \varepsilon^{2} \theta \text { ho }{ }^{1} \text { to }^{1} \mathrm{mo}^{4} \text { tsho }^{3} \mathrm{kho}^{3} \text { tca }^{2} l^{6} \mathrm{o}^{6} \mathrm{i}^{4} \\
& \text { For generations Bunu people love singing Luoxi }{ }^{1} \\
& \theta \text { han }{ }^{1} \mathrm{kan}^{3} \text { tsa }^{6} \text { tsa }^{6} \theta \text { ho } \text { te }^{6} \mathrm{mo}^{4} \mathrm{tu}^{5} \mathrm{li}^{6} \mathrm{lu}^{6} 10^{6} \theta \mathrm{o}^{2} \\
& \text { For ages Yao people eulogize Luotuo } \\
& \text { ñ }{ }^{2} \text { van } 2 \mathrm{to}^{2} \theta \mathrm{ho}^{1} \text { to }{ }^{1} \mathrm{mo}^{4} \mathrm{tsho}^{3} \mathrm{kho}^{3} \mathrm{tca}^{2} \mathrm{lo}^{6} \theta \mathrm{i}^{4} \\
& \text { The elder men are keen on singing Luoxi } \\
& \text { no }{ }^{4} \text { pjo }^{6} \mathrm{mji}^{4} \theta \mathrm{ho}^{1} \mathrm{te}^{6} \mathrm{mo}^{4} \mathrm{tu}^{5} \mathrm{li}^{6} \mathrm{lu}^{6} 10^{6} \theta \mathrm{o}^{2} \\
& \text { The senior women are fond of chanting Luotuo } \\
& \text { n } \varepsilon^{2} \operatorname{tsen}^{2} \theta o^{3} \theta \text { ho }{ }^{1} \text { to }^{1} \mathrm{mo}^{4} \text { tsho }^{3} \mathrm{kho}^{3} \text { tca }^{2} 10^{6} \theta \mathrm{i}^{4}
\end{aligned}
$$

${ }^{1}$ Luoxi and Luotuo refer to the same deity, that is, Miluotuo.
Lads like echoing the song of Luoxi

no ${ }^{4} \operatorname{tsen}^{2} \mathrm{ju}^{2} \theta \mathrm{ho}^{1} \mathrm{te}^{6} \mathrm{mo}^{4} \mathrm{tu}^{5} \mathrm{li}^{6} \mathrm{lu}^{6} 1 \mathrm{o}^{6} \theta \mathrm{o}^{2}$

Lasses love voicing the tune of Luotuo [1]

The world's major inventions in language, religion, philosophy and natural science, as well as the evolution of human life style, have led to the gradual evolution of world culture through multilateral and multidimensional interaction and communication. As a result, the global cultural system have diverged into five cultural circles - "the Buddhist, the Chinese, the nomadic, the Christian and the Islamic" [2]. Scholars have put forward many theories of intercultural communication based on various interactions among and within cultural circles in the global scope. According to C. H. Dodd, the "cultural beliefs" which is composed of "values", "world view" and thinking modes is an important part of the "innercore" in this system [3]. Based on his model, this paper mainly studies the similarities and differences between Bunu Yao's Genesis Epic Miluotuo and the Homeric Epics in terms of religious belief, world outlook, values, and thinking modes, and reveals to some extend the impact of these differences on the translation and transmission of ancient Chinese classics.

\section{Cultural Beliefs}

Belief is composed of views and convictions. It is a way of understanding and judging the right against the wrong, the truth against the false within a certain culture. Cultural beliefs refer to the interpretation of reality or something that function as 
the "window" of perception, through which people can examine themselves and others. It is mainly reflected in religious beliefs, world outlook, values and thinking modes.

\section{Religious Beliefs}

Rooted in the concept of spirit, religion is one of the typical cultural beliefs in human cultural system. In the primitive society, the natural worship, totemism and ancestor worship of the Yao are all inherited in Bunu culture. Bunu Yao believed in natural gods at first. There are a lot of such gods in Miluotuo, such as the god of Vegetation, Thunder, Water, Mountain, Wind and Moon. In totem worship, Bunu people worship sows and eagles, so they have a tradition of fasting for them. In their ancestor worship, votive rituals, both large and small scales, offer sacrifices mainly to Miluotuo, the first human ancestor, and her sons, the leader of Jiuli ethnic group by setting up altars for "Achi" and "Shengong". Since the Tang Dynasty, Taoism and Buddhism have been introduced, and Bunu Yao's view of spirits has been combined with them. In the sacrificial ceremony recorded in the epic, there are not only traditional witches, but also Taogong (from Taoism) and Shigong (from Buddhism), and the former has been gradually replaced by the latter. In general, Bunu religious belief concerns not only the present but also the happiness of the future. This belief links Bunu culture with the culture circle of Buddhism.

Fertility cult prevailed in ancient Egypt and Babylon. For people at that time, the earth stood for the female, the sun for the male, and the bull was considered to be the embodiment of male reproductive performance. As a result, bull worship was very common. Similar to the goddess worship of Bunu Yao, the Earth Goddess of Babylon, Ishtar, enjoyed the same important status as Miluotuo. Following this line, the ancient Greeks, who were deeply influenced by Egyptian and Babylonian culture, accepted this kind of goddess worship. They respected "Diana" as the Supreme God, while Christianity transformed her into Virgin Mary [4]. Later, this worship was passed down to the Crete civilization. After entering the Mycenaean civilization, the Greek land was conquered by the Ionians, the Achaeans and the Dorians successively, as a result of which its religion in the classical period was a mixture of the Crete faith and the Indo-European religion. When it was in Homer's time, Greek religion showed the characteristics of openness and inclusiveness, and the religion in the Homeric Epics didn't have the religious flavor as modern man may have imagined. Gods had the dual attributes of both human and deity, believing in destiny, necessity and predetermination. People believed in sympathetic magic, which was the basis for ceremonies to promote plant, animal and human reproduction. In general, the Egyptian faith attached great importance to the happiness of the afterlife, whereas the belief in Babylon and Greece paid more attention to the well-being of present life. The religious evolution here reflects the connection between ancient Egyptian, Babylonian, Greek culture and Christian culture circle.

\section{World View and Values}

Miluotuo and Homeric Epics reflect people's world view and values of the culture that produces them in different shades. World view represents the conceptual system of a certain culture on the operation of nature and the universe. It is the most basic and essential cultural power, including people's basic views on human nature, man-nature relationship, fate, soul, time and space [3]. Because of its fundamental position in the cultural core, it affects the process of cultural contact and people's perception and understanding of differences.

In Bunu Yao and Greek epics, both people and gods are of round character. They believe that the goodness and kindness are universal, but they also do not ignore the existence of the evil and the dark side of the world. Therefore, it is crucial for them to have a sound judgement and acute insight to distinguish them, so as to punish the undesirable and promote the applaudable. Take Agamemnon for example, he is the great warrior in the battlefield, the loving father of his son, the selfless commander who would sacrifice his daughter to quell Artemis' anger, and he is also the furious and arbitrary grabber who deprived Achilles of his female captive. Similarly, Miluotuo's nine sons, the nine major gods are conscientious and diligent in helping her finishing the task of human creation, but they also mistakenly killed the mouse who cooked meals for them when they were celebrating the completion of their work by accusing that animal for stealing cooked sticky rice. In addition, for finding a right place to settle the future human, Miluotuo asked the eagle to go over mountains and rivers to do so. However, when it came across Kaheng $\left(\mathrm{Kau}^{8} \mathrm{en}^{1}\right)$, one of Miluotuo's son, the god of Mountains on its way, it was attacked and captured by him who thought that it was impossible for his mother to ask someone else to do this job other than him. Therefore, jealousy and disbelief, Kaheng put the eagle in a cage, which caused his own imprisonment later.

The mythological part of Miluotuo mainly embodies the animism in Bunu culture. No matter the deities, people, animals, or plants, they all have human emotions of happiness, anger, sorrow and joy, and are able to communicate with each other. People rely on, but fear for nature, and seek harmonious coexistence with it. For example, the theme of the chapter of "Opening up a New Home" is similar to the concept of exploring and transforming nature embodied in Homeric Epics, as revealed by Odysseus' experience of sailing. In both cases, people undergo and overcome various hardships, understand and improve themselves better, gaining material wealth or mental power. 
There is a similar understanding of fate between Bunu People and Greeks. Many chapters in Miluotuo show how people solved crisis and improved their living conditions. For example, "The Battle Between Monkeys and Locusts" tells how people overcame the locust disaster; "Shooting Suns and Moons" relates to the story of Miluotuo and nine major Gods killing ten Suns and ten Moons which scorched earth with various weapons and plots. These stories embody the spirit of tenacious struggle against fate on part of Bunu people. The Greek understanding of fate is also displayed in Homeric Epics in which People believe that "God helps those who help themselves" and there is no negative thought of "let-it-be". Although both parties have the concept of "man is dominated by fate", they all show a sort of spirit of resistance.

Both epics reflect the superstitious ideas of ghosts and spirits who dwell in the underworld. First of all, based on the idea that the soul has omniscient knowledge, prophetic and magic power, Odysseus went to the underworld to ask for prophecy from his mother's ghost; the ceremony of offering sacrifices to Miluotuo, the supreme Mother God, and the ancestors of the Bunu family are of great significance to the Bunu people, because people hope to get the protection from those spirits, so as to make life smooth and prosperous. Secondly, based on the reincarnation theory of Taoism and Buddhism, the chapter of "Mourning" in Miluotuo has a kind of Cifu ceremony that functions to release the dead souls from purgatory and enables them to "reincarnate". Finally, based on the concept that the power of evil spirits will lead to disease and death, Yao culture also distinguishes the kind ghosts from the malicious ones. Since the former maintains people's peace and happiness, they should be worshipped; whereas the latter does harm to the world, people can only maintain their safety and security by inviting witches or priests who can either drive them away or do them a proper treatment [5].

Plato, the ancient Greek philosopher, believed that the soul was simple and indivisible. It had life and spontaneity, and was a rational and pure existence of the divine world. Because the soul had the desire to pursue the secular, it degenerated to the ground, trapped in the body, and doomed to go through a purification stage before reincarnation. Plato's idea was later echoed by Neo-Platonists similarly. Aristotle once discussed soul and psychology together, and listed On the Soul in the category of "the second philosophy". He thought that the body was only the material, but the soul was the entity with the function of reason, feeling and nutrition. The above understanding of soul and that of the later Gnostic concept constitute the basic view of soul in Western folk beliefs of the following generations.

According to Kramer, the world can be divided into three categories: the "magic", the "mythic" and the "perspectival", and accordingly, there can be three types of views of time and space. When a person enters into the other two worlds in turn from the first, his cognitive latitude increases naturally [6]. The three worlds show the characteristics of one-, two- and threedimensional quality respectively. According to this theory, Miluotuo and Homeric Epics represent similar magic and mythic concept of time and space. On one hand, in these two epics, especially in the mythological part, people have no sense of time and space. For example, once a ritual or magic ceremony is successful, its influence will spread all over the world in an instant, including all people and things without exception; there is no division of "self" and "other", subjects and objects among people; people can communicate with all things, both gods and ghosts, and they believe that all things have spirits. All these are the characteristics of onedimensional magic concept of time and space argued by Kramer.

On the other hand, as the society develops, the epic has been keeping recording macroscopically the emergence of villages, tribes, cities and states and microscopically important events that influences people's life. Thus, in turn the human world in the epic has entered into the two-dimensional mythic spacetime, given the influence from those social-historical changes on their perception and understanding of the world, but the first kind of space-time still plays a role. In terms of the concept of time, Miluotuo mainly embodies the present- and the future-orientation, which is reflected when people holding a votive ceremony and praying for gods to help them improve their present life, and striving to transform the world and create a better life in the future. In contrast, Homeric Epics embody more historical- and present-orientation, as people eulogize heroes' feats and historical achievements, maintaining the security, dignity and honor of this life through military service and other means. In space concept, the sacred and the secular are the two dimensions of the mythic world. In Miluotuo, the worship of Goddess is finally replaced by that of the male god, and similarly, in Homeric epic, Zeus takes the place of his Mother Gaia, both of which are consistent with the fact that the matriarchal society was replaced by the patriarchal and the class society in the real history. The distinction between material and spirit gave birth to the earliest spatial thinking. In that period, the villages were mostly circular, and the most important people and things were in the center of the circle, such as wealth and power, leader's residence, etc.

Values are a series of concepts used by cultural groups or individuals to distinguish whether the behavioral mode, means and objectives of action are correct and valuable, and based on which choices are made [7]. It guides people's behavior and influences the way of cultural communication. 
A large number of chapters and sections in Miluotuo reflect people's moral character, such as loyalty, honesty, respect for the old and love for the young. Violating the above moral principles will destroy the fengshui of the tribe and bring disasters. For instance, the chapters such as "The Battle of Shouyangshan" and “The Battle of Zhuolu” (㴚鹿之战) suggest that the war is caused by the incest between Chiyou's fourth wife and the sun as recorded in its narration. The Greeks in Homeric Epics believe that bravery and valor are the supreme virtues, so the good must be brave and excellent at war, while the bad should be timid, weak or stupid. For example, Agamemnon is the leader who was gallant and skillful in battles. Loyalty is the highest virtue of women, which is indicated typically by Penelope's loyalty to her husband; on the contrary, Helen's betrayal leads to the Trojan War.

As for the sense of mission and the concept of honor and disgrace, the world described in Miluotuo is full of the collectivist sense of mission. Miluotuo, the Creator Goddess, has been endowed with the mission of human creation by her mother since she was born. In order to accomplish this mission, she built painstakingly necessities for the future human world, and gave birth to her children who in turn helped her make preparation and finally complete the task step by step, such as managing mountains and rivers, looking for the place of human inhabitation, planting grains, domesticating livestock, and finally finish the task of making human. In this process, her children, the great gods, were also very conscientious about their work, but they did not take pride in themselves. Instead, they felt guilty for their mistakes. For example, in the chapter of "Burying Wa Liang", Miluotuo was very sorry and grieved because she didn't inform Wa Liang that there was some fortification mechanism in the cave where Kaheng was imprisoned in advance, which resulted in her death. In addition, in "Making Gods of War", Miluotuo mistakenly used the method of producing animals for her task, thus resulting in some monsters and ghosts. Thereafter, she was worried that these spirits would do harm to human beings in the future, so she suffered deep remorse. However, Homeric Epics describes a heroic society. In this social system, heroes are the highest rank. They are either the descendants of deities or the aristocrats of noble families. They feel proud of their heroic achievements and spoils on the battlefield. Since death is inevitable, to die in a battle is the most glorious. Heroes dare to face up to the fate of war and death, in order to be remembered forever. This is the heroic outlook on fate advocated by this epic. When Agamemnon lost the daughter of one of Apollo's priests, his trophy, he grabbed a female captive from Achilles and broke the tradition of spoil distribution. Both of them regarded the loss of female captives as a great humiliation and outrage. The deep reason for that is that female captives represent their own glory; the loss of them means that their social status and noble honor are destroyed.

In addition, Miluotuo exhibits the harmony among people, animals and tribes. The unjust and inhuman situations should be prohibited. Similar to the flood myth in Christian Bible, in this epic, due to the uncontrollable, long-lasting wars across tribes, Miluotuo launched a three-year flood that destroyed all the other human beings, except for a pair of siblings who were protected by Her. In Homeric Epics, there is another kind of harmony, that is, the one between spirit and flesh. Men are believed as the symbol of strength; women are the representative of the beauty and tenderness. Power and beauty are inner and vigorous vitality of human spirit and constitution; and the beauty of figure depends on the body and can transcend the sacred and sanctimonious moral law.

\section{Thinking Modes}

Perception is a process in which people use their senses to perceive and understand the world. It transforms the stimulation of internal and external world into meaningful experience through selection, classification and interpretation [7]. Thinking modes refer to the way people reason and solve problems. The difference in ways of thinking and reasoning will affect the perception experience of audiences across cultures, which in turn leads to the potential difficulty for accurate transmission of meanings. Fortunately, the two epics under discussion, show similar ways of thinking. Therefore, with the help of intertextuality and language adaptation, the translation of Miluotuo will not sound too bewildering to the target audiences in this aspect.

Scholars generally believe that the modern western society mainly follows the linear thinking mode with logic and rationality as the essence, while the oriental people mainly adhere to the indirect and nonlinear way. However, from the epic point of view, both Bunu Yao's Miluotuo and Greek's Homeric Epics embody the intuitive thinking mode and the supernatural causality. The votive ceremony described in Miluotuo reflects that the ancient Yao people thought that although people could improve their lives through efforts, whether they could manage to achieve their wishes depended on the blessing of gods and their ancestors; even the supreme Miluotuo and Her divine sons and daughters were also dominated by fate and required sacrifice activities to eliminate the disasters caused by evil spirits and objects. Likewise, in Homeric Epics, the destiny of human beings has long been limited. They must obey gods' will, or otherwise they will suffer from disasters. Meanwhile, both gods and men are controlled by fate.

\section{CONCLUSION}

All in all, from the perspective of crosscultural communication, this article compares Miluotuo, the Bunu Yao epic from China and Homeric Epics, the 
famous Greek classic, in terms of religious beliefs, world view, values and thinking modes, as well as the probable impact of these cultural differences on the cultural transmission of ethnic classical works. In the first place, the similarity is the main part. It shows that the cross-cultural-circle and worldwide cultural interaction driven by humanistic communication and trade exchanges have given birth to a wide range of cultural commonalities, which are conducive to the spread of the Western Guangxi classic culture, such as that of the Yao. In the second place, the differences, especially those in world outlook and values, need to be further explored, because such discrepancy will lead to prejudice, misunderstanding and other communication obstacles. The similarity among cultures is the basis of cultural identification, while the difference is the key to produce the attraction in aesthetics, poetics, cognition and other aspects. Therefore, how to make use of the difference, apply the perception and reception laws to highlight the special charm of ethnic culture, and minimize the influence of interference factors, is the starting point and foothold of the transmission of ethnic cultures with excellency.

\section{FUNDING}

This article is one of the results of "A Study of the Translation and Transmission of Western Guangxi Ethnic Classics" (Project No.: 18BWW001), a project funded by 2018 Research Project of Philosophy and Social Science Planning of Guangxi Zhuang Autonomous Region, China
An introduction to the author: $\mathrm{Yu} Z \mathrm{Zhang}$, is an associate professor from School of Foreign Languages at Baise University, Guangxi, China. She focuses on the translation Studies of Chinese ethnic classics.

\section{REFERENCES}

1. Zhang S. The Ancient Song of Miluotuo (Vol.1). Nanning: Guangxi Nationalities Publishing House, 2002: 3 .

2. Shi J. Interaction among the World's five Cultural Circles. Guizhou Ethnic Studies, 2002, 4: 22.

3. Dodd, C. H. Dynamics of Intercultural Communication. Shanghai: Shanghai Foreign Language Education Press, 2006: 38-40, 95.

4. Russell B. The History of Western Philosophy (Vol.1). Beijing: The Commercial Press, 2005: 26.

5. Compiling Group of the Brief History of Yao People. A Brief History of Yao People. Beijing: The Ethnic Publishing House, 2008: 268.

6. Kramer E. Trans. Liu Yang. Intercultural Communication in the Context of Globalization. Beijing: Tsinghua University Press, 2015: 141.

7. Chen Guo-Ming \& Starosta W. J. Foundations of Intercultural Communication. Shanghai: Shanghai Foreign Language Education Press, 2007: 33, 43.

8. 基金项目：2018年广西壮族自治区哲学社会科 学规划研究课题——“桂西民族典籍对外译介与 跨文化传播研究”（项目编号：18BWW001). 